\title{
Global Potential Market of Forest Biomass Wood Pellets
}

\author{
Rahayu Lestari \\ International Relation Sciences \\ Lampung University \\ Lampung, Indonesia \\ rahayu.lestari@fisip.unila.ac.id
}

Fisko Arya Kamandanu

International Relation Sciences

Lampung University

Lampung, Indonesia

fisko.arya1084@students.unila.ac.id

\author{
Hadi Prayitno \\ Mechanical Engineering \\ Lampung University \\ Lampung, Indonesia \\ hadi88.tm@gmail.com
}

Yunia

International Relation Sciences

Lampung University

Lampung, Indonesia

yunia.1029@students.unila.ac.id

\author{
Novrianti \\ Forestry \\ Lampung University \\ Lampung, Indonesia \\ bayudesmon@gamil.com
}

\begin{abstract}
The Industrial Revolution 4.0 and society 5.0 encourage disruption not only from technology and business models but also from climate change. The Growth of energy demand is one of the triggers for increasing greenhouse gas emissions. Proper management of forests and plantations can have a multiplier effect, namely conservation, protection of life support systems, and sources of biomass fuel. The International Trade Center shows that Vietnam and Indonesia are the main producers of the Southeast Asia region with an export value of US $\$ 309,220,000$ and US $\$ \mathbf{2 6 , 7 6 4 , 0 0 0}$ respectively in 2019. Meanwhile, Denmark is the world's largest importer with an import value of US

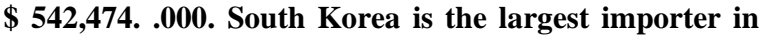
Asia with a value of US \$362,283 in 2019. Lampung Province has a forest area with an area of 1,004,735 hectares of the 94.1 forested land area in Indonesia. Increasing the function of some forests in Lampung to become Energy Plantation Forests can increase the production of wood pellets. The growth of biomass wood pellet production will increase the export balance of Lampung Province. The political will of European Union countries, South Korea and Japan in increasing the use of wood pellets as a fuel for electricity generation is an export opportunity for wood pellets in Lampung Province. The global Wood Pellet market with a value of US \$ 5324 million in 2020 is expected to reach US \$ 8095.4 million by the end of 2026, growing at a CAGR (Compound Annual Growth Rate) of 6.1\% during 20212026. Gorontalo Province, with a planted concession area of 15 thousand hectares, can produce wood pellets of 36 thousand tons/year. 20\% percent of Lampung Forest is increased to THE potential to produce 40 thousand tons/year.
\end{abstract}

Keywords-Forest Biomass wood Pellets, Wood Pellets market, global market, Indonesia Wood Pellets

\section{INTRODUCTION}

The transition from non-renewable energy to renewable energy has driven the growth of the global wood pellets market. The global wood pellet market is growing but with different characteristics in different countries and regions. Indonesia has the opportunity to compete in the global market for biomass wood pellets [1]. The International Trade Center has published data showing that Vietnam and Indonesia are the main producers from the Southeast Asia region with an export value of US\$ 309,220,000 and US\$ 26,764,000 respectively in 2019. Meanwhile, the largest importer in the world is Denmark with a value of US\$ $309,220,000$ and US\$ 26,764,000, respectively. imports of US\$ $542,474,000$ and South Korea of US\$ 362,283 in 2019 (ITC, 2020). Indonesia's potential is not inferior to Vietnam's, including Indonesia excels in the availability of a large enough planted forest land. In addition, the characteristics of Indonesia's forests are tropical climates, high rainfall, and fertile soil. Indonesia has a great opportunity to compete in the global wood pellets market. Starting with optimizing the Asian market share.

Indonesian forests which have an area of 94.1 million hectares have the potential to produce sustainable biomass wood pellets. Not all forest wood is managed into wood pellets biomass. only wood that has sustainable production characteristics is processed into wood pellets as a source of renewable fuel energy. Some biomass energy sources are planted and some use existing trees. The characteristics of these new plants, apart from being a source of wood pellets, also add to the function of the forest as conservation and protection. Meanwhile, wood pellets from existing trees must not damage forest functions. Optimized energy 
plants are useful for reducing the intensity of environmental damage and have a fairly high economic value in international trade activities. Thus, it can increase national economic growth. Some of the plants that have the potential to improve forest function and can be a source of wood pellet biomass is Kaliandra, Bamboo, Sengon, and Mangrove. Planting these plants in the Lampung forest can indirectly optimize the function of the forest in reducing carbon emissions, as a life support system to regulate water systems, prevent flooding, control erosion, and maintain soil fertility. Planting these trees can reduce the intensity of environmental damage that encourages the achievement of Sustainable Development Goals (SDGs) Point 13 regarding climate change actions. Some of these trees provide a multiplier effect to the community around the 2 forests. Apart from being a source of energy, it has a fairly high economic value. So that it contributes to achieving the SDGs, namely, increasing inclusive and sustainable economic growth in Indonesia.

\section{FORMULATION OF THE PROBLEM}

Based on the background above, the formulation of the problem in this research is how the global market opportunities for Indonesian wood pellets are.

\section{Methodology}

This study used qualitative research methods. Creswell (in Noor, 2015, p. 33) [2] states qualitative research as a complex picture, examining words, detailed reports of research objects, and conducting studies in natural situations. The source of data used in this study is secondary data related to the object of research. Data collection techniques used by researchers are document review and literature review. The data collected includes the dynamics of growth in exports and imports of Biomass Wood Pellets in the world, data on the production capacity of Wood Pellets in Indonesia and Lampung. Identifying Indonesia's position in the global Wood Pellet market. Furthermore, identifying and analyzing the potential of the Indonesian Wood Pellet market at a global level.

\section{RESULT AND DISCUSSION}

\section{A. Trade Liberalization}

Trade liberalization is the removal of barriers to the flow of goods and services across national borders [3]. Elimination of these barriers can be in the form of tariffs or non-tariff. Tariff barriers such as customs duties and additional costs in transactions, while non-tariff barriers are in the form of quota regulations, licensing, and other trade terms. Trade liberalization also has a goal, namely a free market which will ultimately have an impact on economic growth. Through trade liberalization, it will also have a fairly good impact, namely making it easier for foreign investment to enter countries that implement it.
Trade liberalization is inseparable from the principle of comparative advantage. Where countries must have advantages in terms of lower production costs compared to other countries. For example, country A has the advantage of natural resources, namely the production of steel at low prices. Meanwhile, country B has the advantage of producing cloth at a lower price. So these two countries will trade with each other because both have production advantages at lower prices than other countries. So that the two countries will benefit from the comparative advantage they have. Therefore, when a country has a comparative advantage and liberalizes trade, that country will have the potential for profit [3].

\section{B. Demand and Supply of Wood Pellet in Global Trade}

The global energy transition has spurred the trading of biomass wood pellets. The United States is the largest producer and consumer [1]. Meanwhile, the United Kingdom, Denmark, and the European Union countries are the export destinations for wood pellets. The largest exporters of wood pellets are still controlled by countries with large land areas such as the United States and Canada. Vietnam is the largest exporter in Southeast Asia. Indonesia is still ranked 26th as an exporter of wood pellets.

Indonesia has a forest area of 94.1 million hectares (BPS, 2020). Lampung's forest is 1.4 million hectares or $1.49 \%$ of Indonesia's total area (BPS Lampung Province, 2020). Forests have the potential to be a source of renewable fuel-based on wood pellets. Forests that are almost $50 \%$ reduced in quality need to be improved. Forests as a source of biomass fuel can be an alternative in optimizing the function of damaged forests. Optimal utilization of forests as a source of biomass fuel can open up great opportunities for Indonesia to take market share of wood pellet-based biomass in Asia to the Global region.

Indonesia has at least 137 village forests and in addition, there is cooperation assistance between the ICCTF project and the Directorate of BPDASPS (Directorate of Social Forestry and Cooperatives). The collaboration in 2014 has successfully built 214 hectares of community forest with calliandra plants, to support the construction of a wood pellet factory [4]. Wood pallet production has reached 36.1 in 2016 and has experienced an average growth of $21 \%$, where the target for wood pellet production in 2026 is to reach 2 million. The target of million wood pellets is 8.4 million per year.

Based on BPS data, Indonesia's biomass product exports to Japan in January-April 2020 reached USD 15.27 million, an increase of 0.7 percent from the previous year. [5] This is one of the Indonesian wood pellet markets in Asia. By optimizing forests as the main source of raw materials for wood pellets, Indonesia has the opportunity to enter the market in various developed countries of the world. 
In 2016 - 2020, the global export value of wood pallets increased by 17 percent, consisting of 45 exporting countries with an average export value increasing every year. This can be seen in the table below

TABLE I. PERCENTAGE OF EXPORT VALUE OF 10 WOOD PALLET EXPORTING COUNTRIES IN 2016 - 2020

\begin{tabular}{|c|c|c|c|c|c|c|}
\hline Rank & Exporters & 2016-2017 (\%) & $2017-2018(\%)$ & 2018-2019 (\%) & $2019-2020(\%)$ & $2016-20120(\%)$ \\
\hline 1 & United States of America & 8 & 21 & 16 & 4 & 13 \\
\hline 2 & Canada & -1 & 24 & 0 & 8 & 7 \\
\hline 3 & Vietnam & 44 & 110 & -15 & 25 & 41 \\
\hline 4 & Latvia & -5 & 23 & 32 & 2 & 13 \\
\hline 5 & Rusian Federation & 32 & 31 & 43 & 8 & 29 \\
\hline 6 & Denmark & 73 & 137 & 51 & 27 & 72 \\
\hline 7 & Austria & 15 & 33 & -4 & -3 & 10 \\
\hline 8 & Estonia & 27 & 2 & -10 & 11 & 7 \\
\hline 9 & Germany & 36 & 38 & 9 & -4 & 20 \\
\hline 10 & Lithuania & 33 & 36 & 23 & -4 & 22 \\
\hline
\end{tabular}

a. Source: ITC calculations based on UN COMTRADE and ITC statistics, processed

From table 1.1 it can be seen that there are the 10 largest wood pallet exporting countries in the world which are calculated on a percentage basis which have a significant increase in the last five years. The United States became the largest exporter in the first position in the world with an average percentage increase in export value of 13 percent (USD thousand 981.593). Then followed by Canada which occupies the second position, Vietnam in the third position with each percentage increase in the value of exports by 7 percent (USD thousand 406.123) and 41 percent (USD thousand 387.302) in the last five years.

TABle II. Percentage Of Export VAlue Of 10 Wood Pallet Exporting Countries In 2016 - 2020

\begin{tabular}{|c|c|c|c|c|c|c|}
\hline Rank & Exporters & 2016-2017 (\%) & 2017- $2018(\%)$ & 2018- $2019(\%)$ & 2019- $2020(\%)$ & 2016-2020 (\%) \\
\hline 21 & Ukraine & $56 \%$ & $96 \%$ & $13 \%$ & $-2 \%$ & $41 \%$ \\
\hline 22 & Slovenia & $37 \%$ & $12 \%$ & $1 \%$ & $-8 \%$ & $10 \%$ \\
\hline 23 & Slovakia & $23 \%$ & $33 \%$ & $21 \%$ & $8 \%$ & $21 \%$ \\
\hline 24 & Bulgaria & $22 \%$ & $21 \%$ & $10 \%$ & $-10 \%$ & $11 \%$ \\
\hline 25 & Indonesia & $76 \%$ & $224 \%$ & $-34 \%$ & $21 \%$ & $72 \%$ \\
\hline 26 & Sweden & $-13 \%$ & $-15 \%$ & $-15 \%$ & $11 \%$ & $-8 \%$ \\
\hline 27 & France & $12 \%$ & $19 \%$ & $-40 \%$ & $-26 \%$ & $-9 \%$ \\
\hline 28 & Spain & $15 \%$ & $17 \%$ & $-21 \%$ & $-1 \%$ & $2 \%$ \\
\hline 29 & Australia & $2484 \%$ & $20 \%$ & $-69 \%$ & $466 \%$ & $725 \%$ \\
\hline 30 & Serbia & $-5 \%$ & $119 \%$ & $-18 \%$ & $-20 \%$ & $19 \%$ \\
\hline
\end{tabular}

Then from table 1.2 shows that there are 10 wood pallet exporting countries globally which are calculated on a percentage basis, experiencing ups and downs in the last five years. Indonesia occupies the 25 th position in wood pellet exports with an average percentage increase in export value reaching 72 percent in the last five years. When viewed from 2016 - 2020, the value b. Source: ITC calculations based on UN COMTRADE and ITC statistics, processed of Indonesia's exports has increased or decreased significantly. Seen in 2016 increased to 226 percent and decreased by 34 percent in 2017. Globally, the export value of wood pallets in the last five years has reached 17 percent with an export value in 2020 of US\$ $4,185,869,000$.

TABLE III. PERCENTAGE OF IMPORT VALUE From 10 COUNTRIES IMPORTING WoOd PALlets IN 2016 - 2020

\begin{tabular}{|c|c|c|c|c|c|c|}
\hline Rank & Importers & 2016-2017 (\%) & $2017-2018(\%)$ & 2018-2019 (\%) & $2019-2020(\%)$ & $2016-2020(\%)$ \\
\hline 1 & United Kingdom & $0 \%$ & $21 \%$ & $12 \%$ & $3 \%$ & $9 \%$ \\
\hline 2 & Netherlands & $42 \%$ & $100 \%$ & $129 \%$ & $157 \%$ & $107 \%$ \\
\hline 3 & Denmark & $50 \%$ & $37 \%$ & $-11 \%$ & $-22 \%$ & $14 \%$ \\
\hline 4 & Italy & $13 \%$ & $32 \%$ & $18 \%$ & $-34 \%$ & $7 \%$ \\
\hline 5 & Japan & $38 \%$ & $123 \%$ & $46 \%$ & $21 \%$ & $57 \%$ \\
\hline 6 & Korea, Republic of & $63 \%$ & $86 \%$ & $-31 \%$ & $-9 \%$ & $27 \%$ \\
\hline 7 & Belgium & $16 \%$ & $12 \%$ & $5 \%$ & $13 \%$ & $11 \%$ \\
\hline 8 & France & $4 \%$ & $22 \%$ & $48 \%$ & $-8 \%$ & $17 \%$ \\
\hline 9 & Austria & $9 \%$ & $2 \%$ & $-14 \%$ & $2 \%$ & $0 \%$ \\
\hline 10 & Germany & $6 \%$ & $0 \%$ & $-16 \%$ & $-17 \%$ & $-7 \%$ \\
\hline
\end{tabular}

From table 1.3 , it can be seen that 10 countries are the largest importers of wood pallets in the world which are calculated as a percentage which have a significant c. Source: ITC calculations based on UN COMTRADE and ITC statistics, processed increase in the last five years. The United Kingdom is the largest exporter in the first position in the world with an average percentage increase in export value of 9 
percent (USD thousand 1.715.047). Then followed by the Netherlands which occupies the second position, Denmark in the third position with each percentage increase in the value of exports by 107 percent (USD thousand 518.402) and 14 percent in the last five years (USD thousand 425.748).

TABLE IV. PERCENTAGE OF IMPORT VALUE FROM 10 COUNTRIES IMPORTING WOOD PALLETS IN 2016 - 2020

\begin{tabular}{|c|c|c|c|c|c|c|}
\hline Rank & Importers & 2016-207 (\%) & $2017-2018(\%)$ & 2018-2019 (\%) & $2019-2020(\%)$ & $2016-2020(\%)$ \\
\hline 21 & Finland & $75 \%$ & $28 \%$ & $11 \%$ & $7 \%$ & $30 \%$ \\
\hline 22 & Canada & $0 \%$ & $17 \%$ & $23 \%$ & $27 \%$ & $17 \%$ \\
\hline 23 & Ireland & $-64 \%$ & $59 \%$ & $55 \%$ & $-16 \%$ & $9 \%$ \\
\hline 24 & Greece & $27 \%$ & $34 \%$ & $-25 \%$ & $2 \%$ & $10 \%$ \\
\hline 25 & Croatia & $16 \%$ & $87 \%$ & $34 \%$ & $25 \%$ & $40 \%$ \\
\hline 26 & Romania & $155 \%$ & $3 \%$ & $7 \%$ & $7 \%$ & $43 \%$ \\
\hline 27 & Serbia & $313 \%$ & $-57 \%$ & $-10 \%$ & $76 \%$ & $81 \%$ \\
\hline 28 & Czech Republic & $28 \%$ & $9 \%$ & $-7 \%$ & $-4 \%$ & $6 \%$ \\
\hline 29 & Norway & $9 \%$ & $69 \%$ & $31 \%$ & $-60 \%$ & $12 \%$ \\
\hline 30 & Slovakia & $-8 \%$ & $42 \%$ & $48 \%$ & $-22 \%$ & $15 \%$ \\
\hline
\end{tabular}

Then from table 1.4 shows that there are 10 wood pallet importing countries globally which are calculated on a percentage basis, experiencing ups and downs in the last five years. It can be seen that these 10 countries experienced a fairly high average increase in the value of imports, such as Israel, Serbia, and Uruguay. Globally, the import value of wood pallets in the last five years has reached 14 percent with an import value of US\$ 4,565,501,000 in 2020.

Based on Government Regulation No. 79 of 2014 concerning national energy policy that Indonesia targets efforts to increase the contribution of new and renewable energy to reach 23 percent by 2025.[6] The target is described in Presidential Regulation Number 22 of 2017 concerning the General National Energy Plan. Representatives of the Indonesian Forest Entrepreneurs Association (APHI) delivered by the Deputy Chair of Natural Forest Production, Bambang Widyantoro, said that the plan to develop wood biomass energy from production forests (non-perhutani) is an area of 800,000 ha of Plantation Forests (HTI) for energy based on calculations on the Development Road Map. Production Forest 2019 - 2045. Wood/biomass production is produced as raw material for energy from Biomass Power Plants (PLTBM). Therefore, the potential for wood pellets in Indonesia is still being achieved in the target of meeting domestic needs.

Apart from these targets, in Indonesia, it has also been developed in one of the provinces, namely Bangkalan, Madura. There is 1 hectare belonging to Mat Juri which is planted with calliandra plants in the Kaliandra Energy Garden planting program. The industrial project also involves other parties such as the ICCTF and the Ministry of Agriculture, so that funding and empowerment of local communities can be carried out. Until the end of this wood pellets project by $\mathrm{CV}$ Pintu Lestari, 15 tons have been stored in the production warehouse [7].

Indonesia's wood pellet export policy sets the export price of wood pellets at US\$ 119/Ton in 2017.[8] One of the variants or wood pellet raw materials, namely the d. Source: ITC calculations based on UN COMTRADE and ITC statistics, processed wood chip variant (wood in the form of shards or fragments) is subject to a selling price of US\$ 61/Ton in 2019 To boost the production of wood pellets [9], the government makes regulations to provide flexibility in the production of wood pellets, namely the issuance of Regulation of the Minister of Environment and Forestry No. P.83/MENHLK/SETJEN/KUM.10/2016 social forestry. The Social Forestry Program itself aims to improve the welfare of the community through a pattern of empowerment and by remaining guided by the sustainability aspect.

With the target of achieving the contribution to new and renewable energy, there has been an umbrella regulation in the development of wood pellet production based on the Kaliandra forest plant. Furthermore, it only requires political will and initiation as well as collaboration between the government and the private sector in realizing it.

\section{Potential of Indonesian Technology in Wood Pellet}

Wood pellets are a type of fuel derived from wood pellets/wood waste, which are more environmentally friendly. Wood pellets are made from wood/hardwood waste such as calliandra wood, which is then processed into powder and then shaped like pellets with a size of $1-3 \mathrm{~cm}$. Wood pellets are intended as an alternative fuel to replace coal because wood pellets come from plants which means they have absorbed more carbon dioxide and become solid carbon so that in the process of burning wood pellets it does not damage the atmosphere. $\mathrm{CO}_{2}$ emissions produced by wood pellets are eight times lower than coal and fuel oil [5]. Calliandra plants can be grown in a variety of soil types, are fast-growing, and produce good quality wood. Calliandra plants usually live at an altitude of 150 to 1,500 meters above sea level with rainfall of $1,000 \mathrm{~mm}$ per year.

This wood pellet industry can be produced from energy plantation forests. Energy plantation forest itself is a forest that is developed commercially and 
optimized to produce wood biomass with a high productivity target and a short period. In the development of the energy plantation forest, there are two types of plants, namely (short rotation coffee SRC) and short rotation wood crops (SWRC). In principle, the two types of plants are intended to get a lot of production with a dense planting system and a short rotation cycle. However, it is very unfortunate that both the SRC and SRWC energy concepts in Indonesia have not been carried out commercially (Rudianto, 2018). Until now still using conventional methods with the aim of only for national construction needs. Indonesia now only knows a few types of stem plants such as Calliandra calothyrsus, Symplocos fasciculata, Vernonia amygdalina, Grilicidia sepium, Piper aduncum, Bauhinia purpurea, Vitex pinnata, and Melastoma malabthricum as well as several other species.

The potential of technology in wood pellet processing can optimize the production of wood pellets. The technology that needs to be developed is still at a simple level, it is predicted that Indonesia and Lampung, in particular, can still reach it.

There are three steps of wood pellet processing :

a) Process recognized (chipping \& milling): The process goes through the process of counting material, drying, grinding, and forming pellets.

b) Drying (drying): The new raw material contains water vapor, therefore the drying process is important. The raw material requirements are only around $6-18 \%$ water vapor

c) Pellet molding (pelleting): After the drying process, the biomass raw material is stamped. Generally, pellet sizes are $6 \mathrm{~mm}, 8 \mathrm{~mm}$, or even more. In this process, there is a high pressure and causes the temperature of the wood to increase and is followed by the plasticization process of lignin (softening). Then the softening process will form glue or adhesive.

There are two types of pellets used in the wood pellet industry in the world today, namely flat die (flat type, stationary/static) and ring die (ring type, and rotating) (Rudianto, 2018).

a) Cooling and Storage (cooling): The wood pellets that come out of the mold will have a curvature of about 80-80 degrees Celsius. Therefore, a cooling process is needed which aims to harden the wood pellet product.

b) Packaging and Distribution: Product packaging usually uses plastic or paper bags. Generally, it weighs around $10-15 \mathrm{~kg}$ and is on the market desirability.

\section{Potential Scheme of Wood Pellet Cooperation}

\section{1) Indonesia and South Korea}

The reason the South Korean government uses Wood Biomass is that the South Korean government implements a Green Growth policy related to the world's agenda to tackle climate change. Upon the implementation of this policy, the South Korean government took steps to increase energy use by using Wood Biomass. However, the need for Wood Biomass raw materials is not fulfilled in South Korea, thus requiring South Korea to cooperate with other countries.

Along with the Green Growth policy, South Korea's demand for wood biomass energy sources has increased. In 2009 the demand for wood pellets increased by $200 \%$. This is the main trigger for the South Korean government to collaborate with countries that have the potential to produce wood pellets, one of which is Indonesia. Indonesia is one of the countries that supply wood pellets. In addition, Indonesia has a fairly large area of land to develop wood pellets. Indonesia is also blessed with biodiversity that can be used as a source of raw material for wood pellets with quality that is not less competitive. Based on these considerations, South Korea and Indonesia made a cooperation agreement through the MoU.

In this collaboration, the governments of South Korea and Indonesia signed an MoU of cooperation on the development of the wood biomass energy industry in 2009 which was signed by the Ministry of Forestry of the Republic of Indonesia, namely DR. (H.C) H.M.S Kaban and the Ministry of Forestry of the Republic of South Korea, namely DR. Chung Kwang Soo. The agreement is carried out with the agreement of mutual assistance and investment in the production and development of wood biomass energy fuels, exchange of experts, researchers, and officials. In addition, South Korea ensures the availability of funds from possible sources in the Republic of Korea for biomass activities, providing access to Indonesian authorities in the planning, implementation, and evaluation of activities decided together within the framework of the MoU [10].

The agreement was carried out with the agreement of mutual assistance and investment in the production and development of wood biomass energy fuels, exchange of experts, researchers, and officials. In addition, South Korea ensures the availability of funds from possible sources in the Republic of Korea for biomass activities, providing access to Indonesian authorities in the planning, implementation, and evaluation of activities decided jointly within the framework of the MOU. Based on the cooperation contained in the MOU in 2009, then the cooperation between the two parties was followed up.

In this cooperation, the two countries have agreed to cooperate in the development of wood pellet energy. Through this cooperation, South Korea has invested 6 trillion in funds. The program that will be carried out in this collaboration is forest and wood waste. In this collaboration, the Indonesian government directly appointed Perhutani while South Korea itself chose PT. 
Solar Park as the executor. Then it was followed up again by holding another meeting in Korea in 2013 where the Indonesian government again appointed Perhutani while South Korea appointed the Korean Green Promotion Agency. This meeting agreed on an MOU on planting Biomass trees and a wood pellet manufacturing plant for bioenergy purposes. Where the executor who will be responsible later is Perhutani and the Korean Green Promotion Agency. With this cooperation in planting and managing waste for the manufacture of wood pellets, South Korea hopes to suppress and replace 5 percent of the use of coal for power generation fuels with alternative energy, namely wood biomass made from wood pellets.

\section{2) Indonesia-Japan Cooperations}

Japan has a green energy policy that prioritizes the use of biomass as renewable energy. This policy includes providing incentives for renewable energy entrepreneurs. By 2030, Japan projects the utilization of biomass energy to reach nine million tons. This policy was used by Indonesia to continue to encourage exports of biomass products, including wood pellets, to Japan. Japan considers Indonesia as one of the potential suppliers of wood pellets with a more efficient cost ratio.

The Japan-Indonesia Economic Partnership Agreement (JIEPA) was signed in 2007 and took force in 2008. The JIEPA agreement in the energy and mineral sector aimed to promote, facilitate investment, and secure the energy and mineral supply of both countries. Indonesia and Japan also cooperated in the biomass sector. Indonesia exported palm shell biomass to Japan in 2016 reached 450 thousand tons, and to Korea reached 400 thousand tons. Total export value to Japan and Korea is worth more than Rp 1 trillion (OG Indonesia, 2017). Japan has targeted up to $4 \%$ from bio-energy to their renewable energy (targeted up to $25 \%$ in 2025). This upcoming demand will be a significant opportunity for Indonesia to export biomass to Japan. In addition, Indonesia and Japan also cooperate in energy technology from waste [11].

\section{E. Data of Energy Forest in Lampung and Indonesia}

TABLE V. PRODUCTION Forest AREA

\begin{tabular}{|l|c|c|c|c|}
\hline \multirow{2}{*}{} & \multirow{2}{*}{ Year } & \multicolumn{3}{|c|}{ Production Forest } \\
\cline { 2 - 5 } & & $\begin{array}{c}\text { Limited Production Forests } \\
(\boldsymbol{H a})\end{array}$ & $\begin{array}{c}\text { Permanent Production } \\
\text { Forests }(\text { Ha })\end{array}$ & $\begin{array}{c}\text { Production Forests that can be } \\
\text { conserved }(\text { Ha })\end{array}$ \\
\hline Lampung & $2017-2019$ & $33.358,00$ & $191.732,00$ & - \\
\hline Indonesia & 2017 & $26.787 .910,70$ & $29.220 .318,67$ & $12.822 .778,99$ \\
\cline { 2 - 5 } & 2018 & $26.787 .910,70$ & $29.202 .047,67$ & $12.847 .548,99$ \\
\cline { 2 - 5 } & 2019 & $26.772 .377,04$ & $29.215 .611,55$ & $12.840 .981,68$ \\
\hline
\end{tabular}

Based on Government Regulation Number 104 of 2015 concerning procedures for changing the designation and function of forest areas, limited production forest is a forest area with the factors of slope class, soil type, and rainfall intensity after each
One of biomass cooperation between IndonesiaJapan is a collaboration in the field of technological research for sustainable development. The SATREPS project as a capacity building for research, training, and conferences in the field of biomass development technology in 2018 was conducted by Indonesia Institute for Sciences (LIPI) and Kyoto University Japan. That project was leading to develop sorghum as biomass energy like a plant that can grow in dry marginal lands [12].

The Indonesian government's efforts, namely the Indonesian trade representatives in Japan through the Trade Attaché of the Indonesian Embassy in Tokyo, collaborated with the Indonesian Trade Promotion Center (ITPC) in Osaka to provide Indonesian exporters with updated information on the Japanese biomass market, especially in the era of the Covid-19 pandemic. Based on BPS data, Indonesia's biomass product exports to Japan in January-April 2020 reached USD 15.27 million, an increase of 0.7 percent from the previous year [13].

In January 2021, Indonesia through the Foundation of Indonesian Institute for Energy Economics (IIEE) in collaboration with the Ministry of Economy, Trade, and Industry (METI) Japan held a workshop aimed at promoting the integration of variable renewable energy (VRE), hydrogen, and low carbon technology in the Indonesian electricity system. From this workshop, several collaborations and collaborations that can be carried out between Indonesia and Japan in new and renewable energy technologies and energy conservation were discussed [14].

Japan and Korea are the fifth and seventh wood pellet importing countries in the global, which are two countries in Asia. This shows the confidence of Japan and Korea in cooperating with Indonesia to support the fulfillment of their domestic wood pellet needs. Meanwhile, the United States is the first exporter of wood pellets in the global market. From the existing cooperation, Indonesia has the opportunity to continue the development of the wood pellets industry and take up the global market to export.

being multiplied by a weighing number having a total value between 125-174, outside protected areas, nature reserve forests, nature conservation forests, and hunting parks. Meanwhile, production forests still have the same factors but the total value is 125 [15]. 
Limited production forests in Indonesia have an average area of 26,728,732.81 hectares over three years (2017-2019). Meanwhile, the production forest area is still wider than the limited production forest, which is $29,212,659.30$ hectares. Then, the average area of converted production forest is only $12,837,103.22$ hectares. There are several types of trees planted in production forests in Indonesia, such as mahogany, teak, pine, jabon, and many more [16].

Based on the Indonesian Central Statistics Agency, Lampung Province within a period of three years (2017-2019) had a production forest area of 33,358.00 hectares (limited production forest) and 191,732.00 (permanent production forest). Meanwhile, for the type of production forest that can be converted, the data is not known. If it is a percentage, the area of limited production forest in Lampung is only $0.12 \%$, and fixed production forest is $0.65 \%$ of the total forest area (limited and fixed production) in Indonesia.

Based on the Production Forest Management Unit, Kesatuan Pengelolaan Hutan Produksi (KPHP), in Lampung Province there are three main regencies that have production forests, namely Way Kanan, Central Lampung, and Mesuji. Then there are five KPHP units, namely Unit III Bukit Punggur (45,075 ha), Unit XVI Gedong Wani (30,243 ha), Unit IV Muara Dua (49,134 ha), Unit VI Register 47 Way Canal (12,500 ha), and Unit V Sungai Buaya ( 44,249 ha).

\section{F. Closing}

With the growing trend of using renewable energy. The wood pellet industry as one of the renewable energy sources is very large. Indonesia (in this case Lampung), with its vast forest potential and good forest community potential, has a great opportunity to be able to optimize. To reach the global wood pellet market share, to increase the export value of renewable energy sources and various other multiplier effects.

\section{ACKNOWLEDGMENT}

This research was funded by the DIPA BLU Universitas Lampung. We appreciate and thank to LPPM universitas Lampung.

\section{REFERENCES}

[1] Thran, Daniela. 2019. The Dynamics of The Global Wood Pellet Markets and Trade-key regions, developments and impact factors. Biofuels, Bioprod. Bioref. 13:267-280.
[2] Noor, J. (2015). Metodologi Penelitian. Prenada Media Group.

[3] Holscher, Jens \& Horst Tomann. 2015. "Palgrave Dictionary of Emerging Markets and Transition Economics". Palgrave Macmillan.

[4] Hakim, Ismatul dan Lukas R. W. 2014. "Hutan Untuk Rakyat: Jalan Terjal Reforma Agraria di Sektor Kehutanan”. Lkis Jogjakarta.

[5] Amirta, Rudianto. 2018. "Pellet Kayu Energi Hijau Masa Depan”. Samarinda: Mulawarman University Press.

[6] Asosiasi Pengusaha Hutan Indonesia, 2019, "Pengembangan Bioenergi Berbasis Hutan".

[7] Asycarya, Daru. 2015. "Dari Hulu Sampai ke Hilir: Model Bisnis Kebun Energi dan Wood Pallet Bangkalan. Riimba Indonesia", Vol.55, April 2015.

[8] Sidabutar, Victor Tulus Pangapoi. 2018. "Kajian Peningkatan Potensi Ekspor Pelet Kayu Indonesia sebagai Sumber Energi Biomassa yang Terbarukan". Journal of Forest Science. 12, 99- 116.

[9] Energi Baru dan Terbarukan Pelet Kayu / Wood Pellet. https://dlhk.bantenprov.go.id/upload/dokumen/Artikel\%201.p df.

[10] Amirta, Rudianto. 2018. "Pellet Kayu Energi Hijau Masa Depan”. Samarinda: Mulawarman University Press.

[11] Karolin, Oktavia Nita. 2019. "Kerjasama Korea Selatan Dan Indonesia Dalam Industri Energi Biomassa Kayu”. Ejournal Ilmu Hubungan Internasional, 7(3).

[12] Yusgiantoro, Filda, Rahmantara Trichandi and Massita Ayu Cindy. Reflections on Energy Cooperation Between Indonesia and Japan "Commemorating 60th Anniversary of IndonesiaJapan Diplomatic Relations". https://www.purnomoyusgiantorocenter.org/reflections-onenergy-cooperation-between-indonesia-and-japancommemorating-60th-anniversary-of-indonesia-japandiplomatic-relations/. (accessed on June 20, 2021).

[13] Purningsih, Dewi. Report: Indonesian and Japan Scientists to Develop Sorghum for https://www.greeners.co/english/indonesian-and-japanesescientists-to-develop-sorghum-for-biofuel/. (accessed on June 15, 2021).

[14] Kementerian Perdagangan Indonesia, 2020, "Manfaat Kebijakan Green Energy Jepang, Kemendag Dorong Ekspor Produk Biomassa ke Negeri Sakura". Diakses melalui

:https://www.kemendag.go.id/storage/article_uploads/ulA0Fo HcC7Lp2OR7g iP1JqF07CW9Twz36yBQLz.pdf .

[15] https://iiee.or.id/2021/02/04/indonesia-japan-workshop-onvariable-renewable-energy-vre-system-integration-hydrogenand-low-carbon-technologies-2021/ (accessed on June 21, 2021)

[16] Keputusan Menteri Keuangan RI No. 1743/KM.4/2019 tentang Penetapan Harga Ekspor untuk Perhitungan Bea Keluar.

[17] www.mutuinstitute.com (accessed on June 2, 2021). 